\title{
SIRT1 activating compounds reduce oxidative stress and prevent cell death in neuronal cells
}

\author{
Reas S. Khan ${ }^{1+}$, Zoe Fonseca-Kelly ${ }^{1+}$, Catherine Callinan ${ }^{2}$, Ling Zuo $^{3}$, Mira M. Sachdeva $^{4}$ and \\ Kenneth S. Shindler ${ }^{1 *}$ \\ 1 Scheie Eye Institute and F.M. Kirby Center for Molecular Ophthalmology, University of Pennsylvania, Philadelphia, PA, USA \\ 2 Department of Ophthalmology, School of Engineering, University of Pennsylvania, Philadelphia, PA, USA \\ ${ }^{3}$ Department of Ophthalmology, Second Hospital of Jilin University, Jilin, China \\ ${ }^{4}$ Department of Ophthalmology, Wilmer Eye Institute, Johns Hopkins Hospital, Baltimore, MD, USA
}

\section{Edited by:}

Eran Meshorer, The Hebrew

University of Jerusalem, Israel

\section{Reviewed by:}

Rafael Linden, Federal University of Rio de Janeiro, Brazil

Deborah Toiber, Harvard Medical School, USA

Conrad Alano, University of California, San Francisco, USA

\section{*Correspondence:}

Kenneth S. Shindler, Stellar-Chance Laboratories, Department of

Ophthalmology, F.M. Kirby Center for Molecular Ophthalmology,

Scheie Eye Institute, University of Pennsylvania, 3rd Floor, 422 Curie Blvd, 51 N 39th st., Philadelphia,

PA 19104, USA.

e-mail:kenneth.shindler@

uphs.upenn.edu

${ }^{t}$ These authors contributed equally to this work.
Activation of SIRT1, an NAD+-dependent deacetylase, prevents retinal ganglion cell (RGC) loss in optic neuritis, an inflammatory demyelinating optic nerve disease. While SIRT1 deacetylates numerous protein targets, downstream mechanisms of SIRT1 activation mediating this neuroprotective effect are unknown. SIRT1 increases mitochondrial function and reduces oxidative stress in muscle and other cells, and oxidative stress occurs in neuronal degeneration. We examined whether SIRT1 activators reduce oxidative stress and promote mitochondrial function in neuronal cells. Oxidative stress, marked by reactive oxygen species (ROS) accumulation, was induced in RGC- 5 cells by serum deprivation, or addition of doxorubicin or hydrogen peroxide, and resulted in significant cell loss. SIRT1 activators resveratrol (RSV) and SRTAW04 reduced ROS levels and promoted cell survival in RGC-5 cells as well as primary RGC cultures. Effects were blocked by SIRT1 siRNA. SIRT1 activators also increased expression of succinate dehydrogenase $(\mathrm{SDH})$, a mitochondrial enzyme, and promoted deacetylation of PGC-1 $\alpha$, a co-enzyme involved in mitochondrial function. Results show SIRT1 activators prevent cell loss by reducing oxidative stress and promoting mitochondrial function in a neuronal cell line. Results suggest SIRT1 activators can mediate neuroprotective effects during optic neuritis by these mechanisms, and they have the potential to preserve neurons in other neurodegenerative diseases that involve oxidative stress.

\footnotetext{
Keywords: resveratrol, SIRT1, neuroprotection, oxidative stress, optic neuropathy, mitochondria
}

\section{INTRODUCTION}

Optic neuritis is an inflammatory demyelinating optic nerve condition that often occurs in multiple sclerosis (MS) patients (Arnold, 2005). Axonal loss also occurs in optic neuritis patients and correlates with decreased vision (Trip et al., 2005; Fisher et al., 2006). Significant loss of retinal ganglion cells (RGCs), the neurons that comprise the optic nerve, occurs in experimental models of optic neuritis (Guan et al., 2006; Shindler et al., 2006; Quinn et al., 2011), providing useful models of neuronal degeneration in demyelinating disease of the central nervous system. Recent studies demonstrated that RGC and optic nerve injury are accompanied by increased reactive oxygen species (ROS) (Lieven et al., 2006), predominantly in mitochondria, the primary source of cellular ROS production and detoxification (Andreyev et al., 2005). Increased ROS is linked to neurodegenerative diseases (Kalman and Leist, 2003), including optic neuropathies (Qi et al., 2003, 2007). Although ROS are key mediators of CNS injury in MS and its animal models (Cowden et al., 1998; Mohamed et al., 2003), contributions of mitochondria to ROS activity and cell death are not well understood.

SIRT1 is a member of the sirtuin gene family encoding NAD+-dependent deacetylases that deacetylate histones and prolong survival (Imai et al., 2000; Baur et al., 2006). Sirtuins deacetylate numerous protein targets involved in various cellular pathways, including stress responses, apoptosis, and axonal degeneration (Yang and Sauve, 2006). Sirtuin activators and inhibitors modulate SIRT1 activity by altering the $\mathrm{K}_{\mathrm{m}}$ for its substrates (Baur, 2010). We previously showed three distinct SIRT1 activators attenuate RGC loss induced by experimental optic neuritis (Shindler et al., 2007, 2010; Fonseca-Kelly et al., 2012). The mechanism of this neuroprotection is not fully understood, but is dependent on SIRT1, as SIRT1 inhibitors block the protective effects, and the mechanism does not involve suppression of inflammation, suggesting other pathways must be involved.

Resveratrol (RSV) is a phytoalexin present in numerous plants (Dong, 2003). RSV has multiple protective effects including cardioprotection (Chu et al., 2011), antiaging (De la Lastra and Villegas, 2005), and defense against metabolic and neurodegenerative diseases (Pallàs et al., 2009). RSV improves mitochondrial function and protects against metabolic disease by activating SIRT1 to deacetylate the mitochondrial co-enzyme PGC-1 $\alpha$ (Lagouge et al., 2006). In addition, RSV exhibits antioxidant activities (Sun and Spranger, 2005), ROS scavenging (Burkitt and Duncan, 2000), and regulates antioxidase expression (Murias et al., 2005). RSV affects different metabolic pathways depending on cell type, cell state, and duration and dosage of treatment. 
At the same time, RSV has numerous intracellular targets including transcription factors/cofactors, thus regulating metabolic homeostasis and resulting in multiple pleiotropic effects (Barger et al., 2008; Wang et al., 2009).

Therefore, it is important to determine specific signaling pathways that RSV and other SIRT1 activators promote in neurons, to better understand mechanisms of their neuroprotective effects. Unfortunately, no specific RGC cell line exists. In the present study, the ability of SIRT1 activators to prevent cell death induced by oxidative stress was evaluated using RGC-5 cells. While the RGC-5 cell line was originally reported to be a transformed rat cell line with features of RGCs (Krishnamoorthy et al., 2001), it has since been recharacterized (Van Bergen et al., 2009), demonstrating features of mouse photoreceptors. RGC-5 cells retain some characteristics of neurons, including differentiation into neuronal-like cells with neurite outgrowth induced by treatment with staurosporine (Frassetto et al., 2006; Wood et al., 2010). The ability of two SIRT1 activators, RSV and SRTAW04, to promote SIRT1 activity, reduce ROS accumulation, and increase markers of mitochondrial function was assessed in RGC-5 cells, and because of the limits of the RGC-5 cell line, key effects were also examined in primary RGCs isolated from neonatal mice.

\section{MATERIALS AND METHODS \\ MICE}

Six-week-old female SJL/J mice were purchased from the Jackson Laboratory (Bar Harbor, ME) for induction of experimental optic neuritis. For isolation of primary retinal cells, 3-5-dayold C57/Bl6 mouse pups were removed from litters of timedpregnant mice (Jackson). Treatment of animals was reviewed and approved by the Institutional Animal Care and Use Committee at the University of Pennsylvania.

\section{EXPERIMENTAL AUTOIMMUNE ENCEPHALOMYELITIS (EAE)}

EAE was induced as previously described (Shindler et al., 2006). Briefly, eight-week-old female SJL/J mice were anesthetized with ketamine/xylazine and were injected subcutaneously at two sites on the back with $0.1 \mathrm{~mL}$ solution containing $0.5 \mathrm{mg} / \mathrm{mL}$ proteolipid protein peptide 139-151 (GenScript, Piscataway, NJ) emulsified in complete Freund adjuvant (CFA; Difco, Detroit, MI) containing $2.5 \mathrm{mg} / \mathrm{mL}$ Mycobacterium tuberculosis (Difco). Control mice were injected with equal volumes of PBS and CFA. All mice were injected with $200 \mathrm{ng}$ pertussis toxin (List Biological, Campbell, CA) in $0.1 \mathrm{~mL}$ PBS intraperitoneally on day 0 (day of immunization) and again on day 2.

\section{RGC-5 CULTURE AND VIABILITY}

Cultures of RGC-5 cells (ATCC, Manassas, VA) were maintained in growth medium containing low-glucose Dulbecco's modified Eagle's medium (DMEM) containing 10\% fetal bovine serum, $100 \mathrm{U} / \mathrm{mL}$ penicillin, and $100 \mu \mathrm{g} / \mathrm{mL}$ streptomycin (SigmaAldrich, St. Louis, MO) in a humidified atmosphere of $95 \%$ air and $5 \% \mathrm{CO}_{2}$ at $37^{\circ} \mathrm{C}$, as described by Krishnamoorthy et al. (2001). Cells were passaged every 3-4 days, with a doubling time of 18-20 h. During each experiment, cells were plated at a concentration of $1 \times 105$ cells $/ \mathrm{mL}$ and after $16 \mathrm{~h}$ treated with various concentrations of RSV (Sigma-Aldrich) or SRTAW04 (Sirtris, a
GSK company, Cambridge, MA) dissolved in DMSO with or without $\mathrm{H}_{2} \mathrm{O}_{2}$ for $24 \mathrm{~h}$. To obtain staurosporine-differentiated RGC- 5 cells, cells were exposed to $1 \mu \mathrm{M}$ staurosporine (Cayman Chemical, Ann Arbor, MI) for 6 h, washed three times with PBS and then recovered in culture medium for 1 day. Control cells were treated with DMSO only. DMSO concentration in each well was below $0.5 \% \mathrm{v} / \mathrm{v}$. For doxorubicin experiments, cells were plated at $1 \times 105$ cells $/ \mathrm{mL}$ and after $16 \mathrm{~h}$ treated with $1 \mu \mathrm{M}$ of doxorubicin (Sigma, St. Louis, MO) for another $24 \mathrm{~h}$. For serum starvation experiments, media were replaced with serum free media and cells were grown for $24 \mathrm{~h}$. Cell viability was measured by trypan blue staining and counted on a hemocytometer. Alternatively, cell viability was assessed using PrestoBlue ${ }^{\mathrm{TM}}$ Cell Viability Reagent (Invitrogen, Grand Island, NY). Twenty-two microliter was added to each well and incubated for $20 \mathrm{~min}$, and fluorescence was read on a plate reader excited at $570 \mathrm{~nm}$ with non-conjugated light emissions collected at $610 \mathrm{~nm}$.

\section{PRIMARY RGCs}

The retina was removed from 3- to 5-day old C57/Bl6 mice and cells were dissociated as described previously for neonatal rat retina (Heng et al., 1999). Briefly, retinas were dissociated in solution containing $0.45 \mathrm{U}$ papain (Worthington, Lakewood, $\mathrm{NJ}$ ) for $30 \mathrm{~min}$ at $37^{\circ} \mathrm{C}$. After digestion, the retinal tissue was rinsed twice with DMEM before being transferred into Neurobasal medium containing 1\% BSA (Sigma) B27-supplement (1:50, Gibco) and penicillin/streptomycin (Gibco). Then, tissue was triturated and passed through a cell strainer before seeding of the isolated cells onto poly-D-lysine $(0.1 \mathrm{mg} / \mathrm{ml}$, molecular weight $<300,000 \mathrm{Da}$, Sigma) and laminin $(20 \mu \mathrm{g} / \mathrm{ml}$, Sigma $)$ coated chamber slides. To quantify RGC survival, chamber slides were washed twice with PBS and fixed in $4 \%$ paraformaldehyde for $15 \mathrm{~min}$. Fixed cells were permeabilized using $0.3 \%$ Triton X-100 and blocked with $1 \%$ BSA in PBS for $1 \mathrm{~h}$ followed by incubation with anti Brn3a antibody (Santa Cruz biotechnology, Santa Cruz, CA) over night at $4^{\circ} \mathrm{C}$. After washing with PBS, fluorescence-labeled secondary antibodies (Invitrogen) were applied for $1 \mathrm{~h}$ at room temperature (RT). Finally, cells were embedded in mounting medium containing DAPI (Vector labs, Burlingame, CA), pictures were taken using a fluorescence microscope (Eclipse E600; Nikon, Tokyo, Japan), at $10 \times$ magnification and the Brn3a specific RGCs were counted by a masked investigator.

\section{MitoSOX STAINING}

MitoSOX Red (Invitrogen) mitochondrial superoxide indicator is a fluorogenic dye for selective detection of superoxide in the mitochondria of live cells. For RGC-5 cultures, MitoSOX reagent was diluted to a final concentration of $3 \mu \mathrm{M}$ in warm DMEM $1 \%$ FBS and added to the cells. After 15 min incubation at $37^{\circ} \mathrm{C}$, cells were fixed with $4 \%$ paraformaldehyde for $10 \mathrm{~min}$, mounted onto glass slides with Mowiol mounting medium, and observed under a Eclipse E600 (Nikon, Tokyo, Japan) fluorescence microscope using excitation $510 \mathrm{~nm} /$ emission $580 \mathrm{~nm}$. For optic nerves, mice were anesthetized with ketamine/xylazine and the optic nerves were removed, washed with PBS and incubated in $5 \mu \mathrm{M}$ MitoSOX Red for $30 \mathrm{~min}$ at $37^{\circ} \mathrm{C}$. After incubation, nerves were washed three times with PBS and mounted in OCT. Five micromole 
cross-sections were made, viewed by fluorescent microscopy, and photographed at $20 \times$ magnification. One photograph centered within each optic nerve cross section was taken by a blinded investigator using a standard exposure, and staining was quantified by calculating the optical density using Image J software (nih.gov).

\section{WESTERN BLOT}

Cell cultures were washed twice with PBS, trypsinized for $5 \mathrm{~min}$, diluted with $10 \times$ volume of PBS and centrifuged at $2000 \mathrm{~g}$ for $10 \mathrm{~min}$. Pellets were lysed in RIPA buffer $(150 \mathrm{mM} \mathrm{NaCl}$, $1 \%$ NP-40, 0.5\% desoxycholic acid, $0.1 \%$ SDS and $50 \mathrm{mM}$ Tris, $\mathrm{pH} 8$ ) to obtain total protein, and protein content was measured with the BCA protein assay kit (Thermo scientific, Rockford, IL). Proteins $(30 \mu \mathrm{g})$ were separated by polyacrylamide gel electrophoresis using 10\% SDS-polyacrylamide gels under reducing conditions, then transferred with semidry blotting (Bio-Rad, Hercules, CA) to Nitrocellulose High bound ECL membranes (GE Healthcare Biosciences, Pittsburgh, PA). Membranes were blocked with Odyssey Blocking Buffer (Licor Biotechnology, Lincoln, NE) for $1 \mathrm{~h}$ at RT. Rabbit polyclonal antibodies against SIRT1 (AbCam, Cambridge, MA) were used at a 1:1500 dilution overnight at $4^{\circ} \mathrm{C}$. As secondary antibody, IRDye ${ }^{\circledR} 800 \mathrm{CW}$ Goat anti-rabbit IgG (Licor) was incubated at a 1:5000 dilution for $1 \mathrm{~h}$ at RT. Rabbit polyclonal SOD2 (GeneTex, Irvine, $\mathrm{CA}$ ) and mouse monoclonal succinate dehydrogenase $\mathrm{b}$ (SDHb) (Abcam, Cambridge, MA) antibodies were used at 1:1000 dilutions. As secondary antibody, IRDye ${ }^{\circledR} 800 \mathrm{CW}$ goat anti-rabbit IgG and IRDye ${ }^{\circledR} 600$ goat anti-mouse IgG were used at a dilution of 1:5000. Fluorescence was visualized using Odyssey infrared imaging system (Licor). For normalization of signals, blotted membranes were stained for $\beta$-actin (Sigma). The intensity of each band was determined using Image J software (nih.gov).

\section{DETECTION OF PGC-1 $\alpha$ ACETYLATION}

PGC-1 $\alpha$ was immunoprecipitated from cell extract $(500 \mu \mathrm{g}$ of nuclear protein) using anti-PGC-1 $\alpha$ antibody (Santa Cruz). Immunoprecipitated PGC- $1 \alpha$ was electrophoresed in SDS-PAGE and immunoblotted with antibody specific for acetylated lysine (Cell Signaling Technology, Boston, MA) to detect acetylation, or antibody specific for PGC- $1 \alpha$ (Novus Biologicals, Littleton, CO) to detect total PGC- $1 \alpha$ levels.

\section{JC-1 STAINING OF MITOCHONDRIAL MEMBRANE POTENTIAL}

JC-1 (Immunochemistry Technologies, Bloomington, MN) staining was performed according to manufacturer's instructions to assess mitochondrial membrane potential (Cossarizza et al., 1993). In healthy cells due to higher mitochondrial membrane potentials, JC-1 forms fluorescent "J aggregates" that appear red. However, JC-1 exists as a monomer at low mitochondrial membrane potential, as seen in apoptotic cells, and appears green. Thus, the emission of this cyanin dye can be used as a measure of mitochondrial membrane potential. A stock solution of JC- 1 was prepared at $4 \mathrm{mg} / \mathrm{mL}$ in dimethylsulfoxide (DMSO). The stock JC-1 solution was added drop-wise, while vortexing, to control medium to a final concentration of $10 \mu \mathrm{g} / \mathrm{mL}$. The diluted JC-1 solution was then passed through a $0.2-\mu \mathrm{M}$ syringe filter (GeneMate, Kaysville, UT) and added to RGC-5 cultures for $15 \mathrm{~min}$ at $37^{\circ} \mathrm{C}$. After incubation, staining solutions were decanted, each dish was washed three times with Ringer's buffer [in $\mathrm{mM} ; 130 \mathrm{NaCl}, 5 \mathrm{KCl}, 2 \mathrm{CaCl}_{2} .2 \mathrm{H}_{2} \mathrm{O}, 1 \mathrm{MgSO}_{4}, 8 \mathrm{NaOH}$, $1 \mathrm{NaPO}_{4}, 5.5 \mathrm{D}$-glucose $\left.(\mathrm{pH} \mathrm{7.4})\right]$ at $37^{\circ} \mathrm{C}$, and cells were left in fresh Ringer's buffer. Live cell images were acquired using the Argon laser on a fluorescent microscope (Eclipse E600; Nikon). JC-1 was excited at $488 \mathrm{~nm}$ and non-conjugated light emissions were collected at $530 \mathrm{~nm}$ (green) and conjugated at $590 \mathrm{~nm}$ (red). The level of JC-1 staining was quantified by photographing cultures with a standard exposure and calculating the optical density of staining using Image J software.

\section{TMRM STAINING OF MITOCHONDRIAL MEMBRANE POTENTIAL}

TMRM (Immunochemistry Technologies, Bloomington, MN) staining was performed according to manufacturer's instructions. Differentiated RGC-5 cells after treatment were incubated with $100 \mathrm{nM}$ of TMRM for $15 \mathrm{~min}$ and washed twice with washing buffer. Live cell images were acquired using the fluorescent microscope (Eclipse E600; Nikon). The level of TMRM staining was quantified by photographing cultures with a standard exposure and calculating the optical density of staining using Image J software.

\section{SIRT1 INHIBITION WITH SIRNA}

SIRT1-specific siRNA, and control siRNA were Silencer select predesigned siRNAs from Life Technologies (Invitrogen) and experiments were performed according to manufacturer's instructions. Briefly, mouse primary retinal cells or differentiated RGC- 5 cells were treated with $25 \mathrm{~nm}$ of either SIRT1 specific siRNA or control siRNA using lipofectamine RNA iMAX transfection reagent. $24 \mathrm{~h}$ later, the cells were treated with $\mathrm{H}_{2} \mathrm{O}_{2}$ with or without drug treatment and cell survival was assessed $48 \mathrm{~h}$ after transfection.

\section{STATISTICS}

Data are expressed as means \pm SEM. For cell viability, SIRT1 activity, and western blot analysis, differences between culture groups were assessed using One-Way ANOVA followed by Student Neuman-Keuls post-hoc test. Statistical differences were considered significant at $P<0.05$.

\section{RESULTS \\ ROS ACCUMULATE IN OPTIC NEURITIS AND INDUCE TOXICITY IN RGC-5 CELLS}

MitoSOX Red detection of superoxide within mitochondria was used to confirm prior studies suggesting a role of ROS accumulation in optic neuritis (Qi et al., 2007) in mice with EAE, a model of MS. EAE was induced in female SJL/J mice by immunization with proteolipid protein peptide, and mice were sacrificed 11 days later, when optic nerve inflammation is known to peak (Shindler et al., 2006, 2008). Ten optic nerves of 5 EAE mice and 5 control mouse optic nerves were isolated and incubated with MitoSOX Red. Fluorescent microscopy of cryosectioned EAE specimens revealed an increase in the superoxide anion compared to control optic nerves (Figure 1).

MitoSOX staining was used to determine whether cultured RGC-5 cells demonstrate similar superoxide accumulation in mitochondria in response to various stressors, as seen in RGCs 

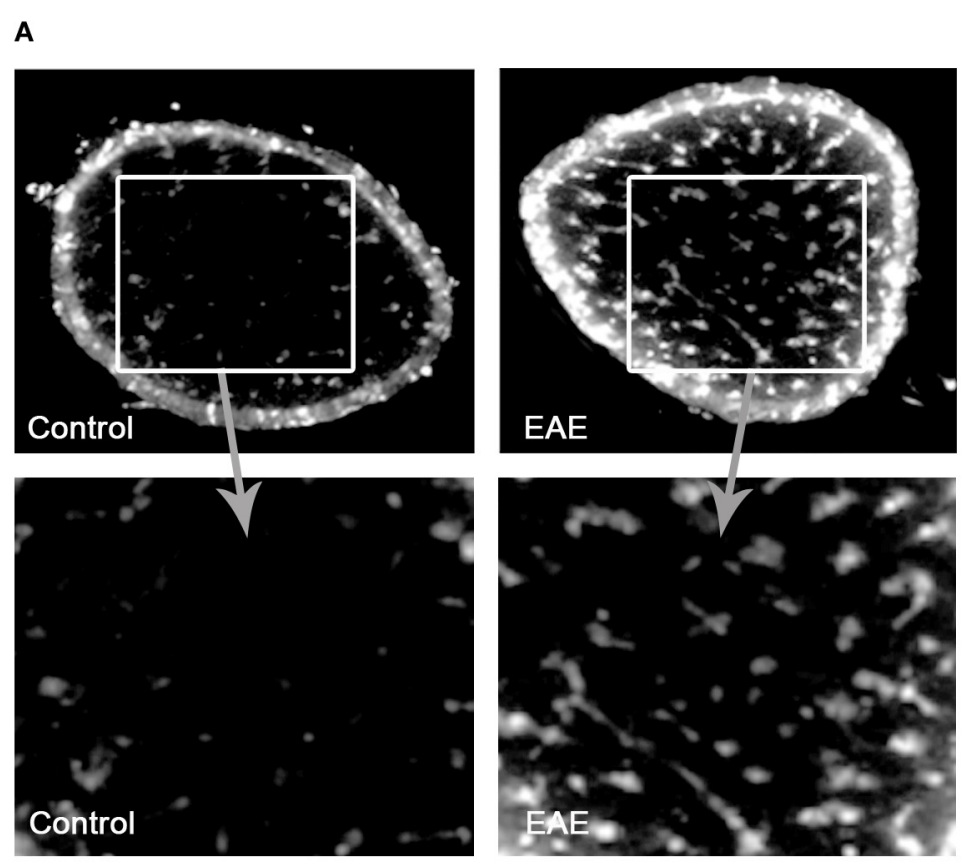

B

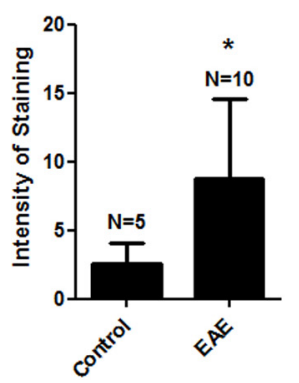

FIGURE 1 | ROS accumulate in the optic nerve during EAE. Eight-week-old female SJL mice were immunized with proteolipid protein and were sacrificed 11 days later. Optic nerves of EAE and control mice were isolated and stained with MitoSOX Red. (A) Cross-sections show high levels of MitoSOX Red staining, a marker of superoxide anion, throughout the parenchyma of EAE optic nerves, with significantly less staining in control optic nerves. One representative nerve from a control mouse, and one EAE optic nerve, is shown at $10 \times$ original magnification (top) and $40 \times$ original magnification (bottom). (B) The average intensity of MitoSOX staining is significantly higher in EAE optic nerves as compared to control optic nerves $(* p<0.05)$. axons in EAE optic neuritis. Cell viability was also measured. RGC-5 cells were plated and incubated for $16 \mathrm{~h}$ prior to being stressed by removal of serum, or by addition of doxorubicin or hydrogen peroxide. Serum starvation of the RGC-5 cells showed a significant decrease in cell viability by $16 \mathrm{~h}$ after serum removal, with an associated increase in MitoSOX Red staining (Figures 2A,B). Treatment with $1 \mu \mathrm{M}$ doxorubicin induced a significant decrease in RGC-5 cells compared to control cultures, beginning within $6 \mathrm{~h}$ of incubation, also with a robust increase in the superoxide staining (Figures 2C,D), and similar RGC-5 cell loss and ROS accumulation occurred in cultures treated with $500 \mu \mathrm{M}$ hydrogen peroxide (Figures 2E,F).

Because RGC-5 cells are a transformed, dividing cell line, we next pretreated RGC-5 cells with staurosporine $(1 \mu \mathrm{M}$ for $6 \mathrm{~h}$ ), which drives neuronal differentiation with sprouting of neurites (Frassetto et al., 2006) (Figure 3A). Serum withdrawal and doxorubicin induce cell loss and ROS accumulation in differentiated RGC-5 cells (data not shown) as in undifferentiated cells (Figure 2). We also directly introduced oxidative stress by treating with hydrogen peroxide and found a dose dependent loss of differentiated RGC-5 cells (Figure 3B). We used hydrogen peroxide $(500 \mu \mathrm{M})$ for subsequent experiments to directly drive oxidative stress.

\section{SRTAW04 AND RSV ATTENUATE NEURONAL CELL DEATH}

Previous studies showed SIRT1 activators significantly attenuate RGC loss in experimental optic neuritis (Shindler et al., 2007, 2010; Fonseca-Kelly et al., 2012), although molecular mechanisms of effects on neuronal survival are not well understood. We investigated whether similar effects can be reproduced in neuronal cultures. RGC- 5 cells were differentiated by $1 \mu \mathrm{M}$ staurosporine for $6 \mathrm{~h}$ and then grown in media with $10 \%$ serum for $24 \mathrm{~h}$. After 

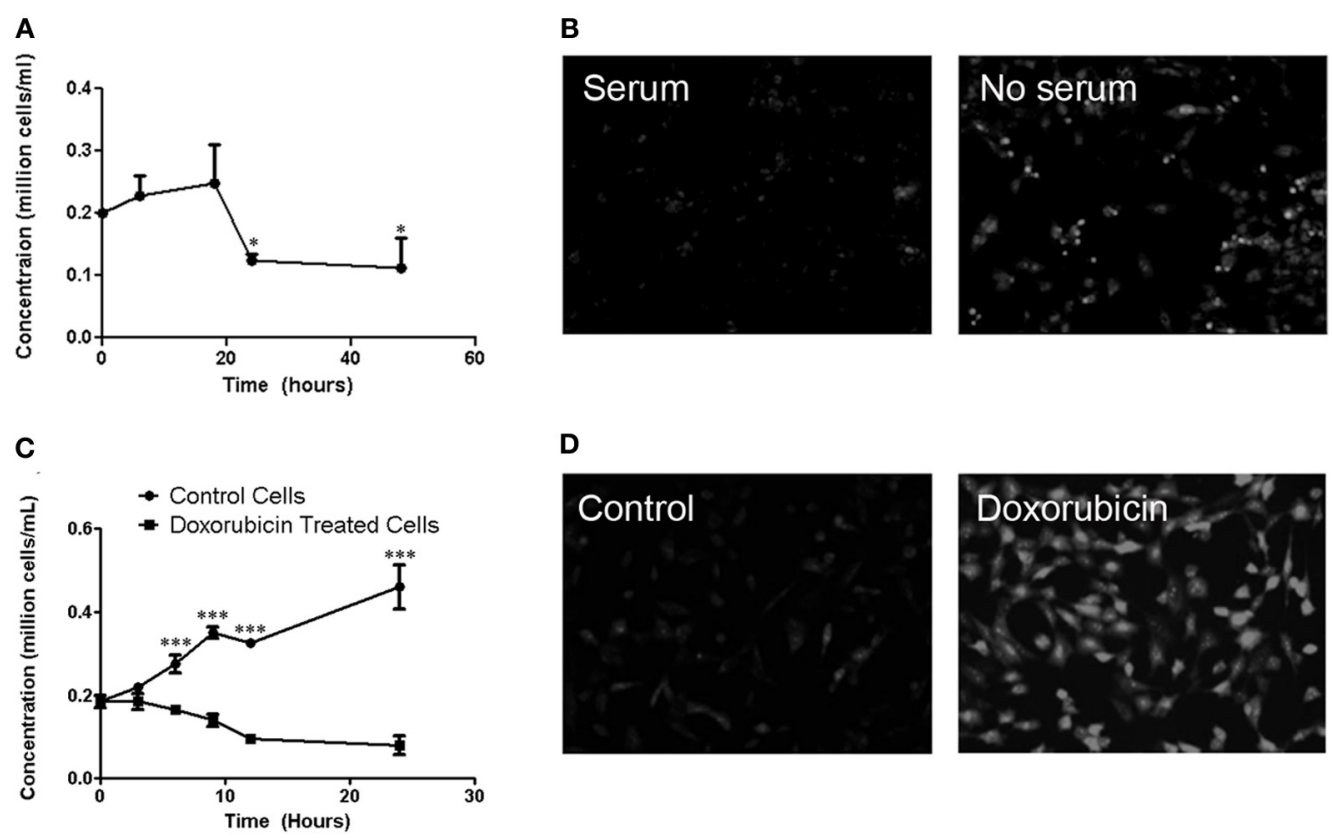

D
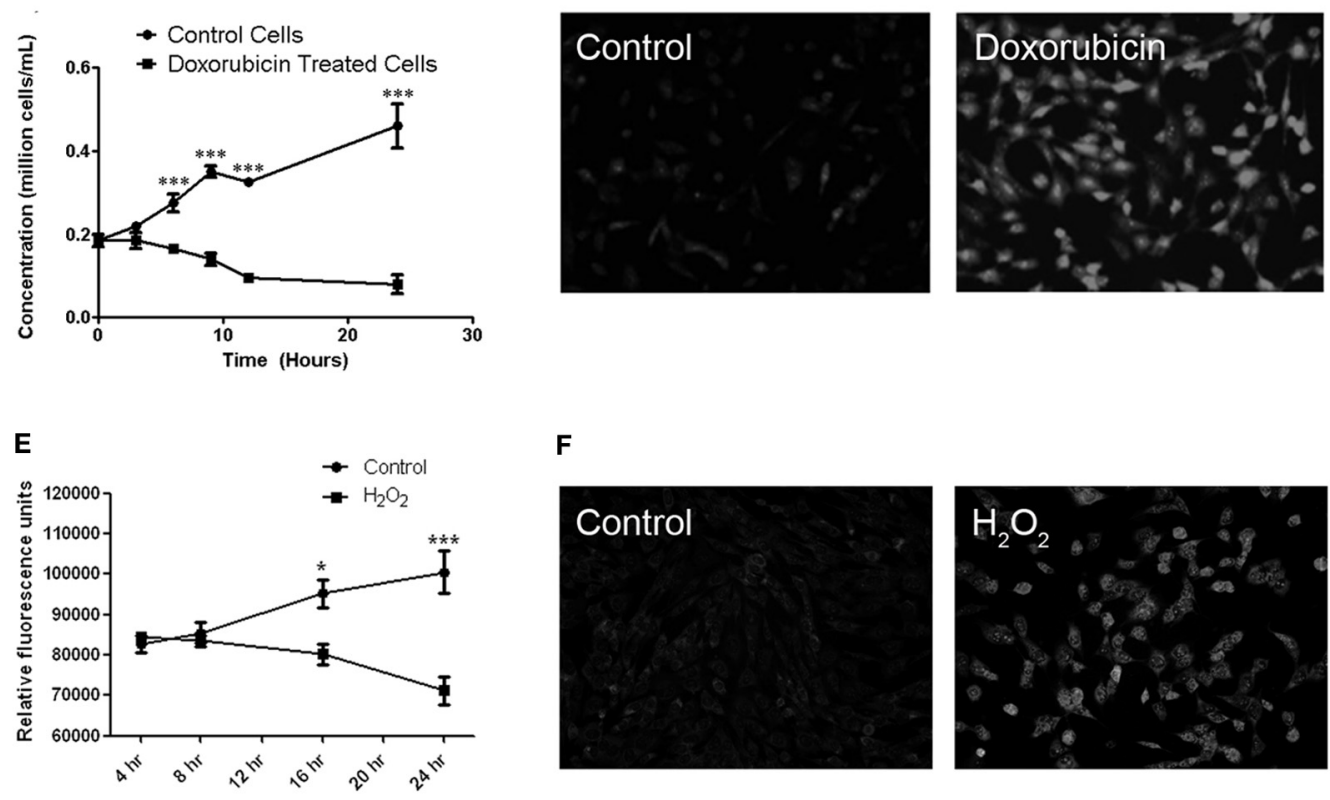

F
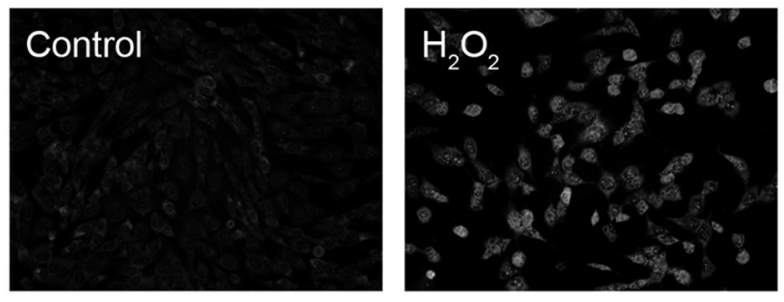

FIGURE 2 | Cell viability and MitoSOX staining in cultured RGC-5 cells in response to stressors. (A) RGC-5 cells were plated in serum-containing medium for $16 \mathrm{~h}$ and then stressed by serum starvation of RGC-5 cells for the next $48 \mathrm{~h}$. A significant decrease in numbers of viable cells, counted by trypan blue exclusion, $\left({ }^{*} p<0.05\right)$ occurs by $24 \mathrm{~h}$ after serum removal. (B) There is an associated increase in the number of MitoSOX Red staining cells in serum-deprived cultures as compared to serum-containing cultures. (C) RGC-5 cells were plated in serum-containing medium for $16 \mathrm{~h}$ and then treated with $1 \mu \mathrm{M}$ doxorubicin for $24 \mathrm{~h}$. Cell viability was assessed by trypan blue exclusion. Doxorubicin induces a significant decrease $\left({ }^{* * *} p<0.001\right)$ in RGC-5 cell number compared to control cultures, beginning within $6 \mathrm{~h}$ of incubation. (D) Increased superoxide staining is observed in doxorubicin treated RGC-5 cultures. (E) RGC-5 cells were plated in serum-containing medium for $16 \mathrm{~h}$, then treated with $500 \mu \mathrm{M} \mathrm{H} \mathrm{O}_{2}$ for $24 \mathrm{~h}$. Cell viability was assessed using PrestoBlue ${ }^{\mathrm{TM}}$ Cell Viability Reagent. A significant decrease in cell viability $(* p<0.05$; *** $p<0.001)$ occurs after $\mathrm{H}_{2} \mathrm{O}_{2}$ treatment. (F) $\mathrm{H}_{2} \mathrm{O}_{2}$ induces an increase in MitoSOX staining.
$24 \mathrm{~h}$, cells were observed for their morphological features. Their somas became rounder and neurites gradually increased, similar to prior studies (Frassetto et al., 2006). The cells contacted each other with multiple long neurites, features of neuronal differentiation (Figure 3A). Differentiated cells were then pretreated with SIRT1 activating compounds, $0.25 \mu \mathrm{M}$ RSV or $5 \mu \mathrm{M}$ SRTAW04, for $30 \mathrm{~min}$ before addition of $500 \mu \mathrm{M} \mathrm{H}_{2} \mathrm{O}_{2}$. Treatment with both SRTAW04 and RSV showed significant reduction of RGC-5 cell death compared to untreated cells, $24 \mathrm{~h}$ after $\mathrm{H}_{2} \mathrm{O}_{2}$ addition; treatment with a known SIRT1 inhibitor (Baur, 2010), nicotinamide (NAM; $200 \mu \mathrm{M}$ ), attenuated this protective effect whereas NAM treatment alone did not alter cell viability (Figure 3C). We also evaluated effects of higher RSV and SRTAW04 concentrations on cell survival, but found no increased benefit of RSV at concentrations higher than $0.25 \mu \mathrm{M}$, nor SRTAW04 higher than $5 \mu \mathrm{M}$ (data not shown).

\section{SRTAW04 AND RSV REDUCE ROS IN RGC-5 CELLS}

To investigate whether RSV and SRTAW04 attenuate superoxide accumulation produced by hydrogen peroxide treatment, RGC5 cells were pretreated with $0.25 \mu \mathrm{M}$ RSV or $5 \mu \mathrm{M}$ SRTAW04, as used for the cell viability experiments. Cells were stained with MitoSOX Red $24 \mathrm{~h}$ after exposure to $500 \mu \mathrm{M} \mathrm{H}_{2} \mathrm{O}_{2}$, and experiments were repeated using both differentiated and non-differentiated RGC-5 cells. MitoSOX staining in differentiated cells showed that $\mathrm{H}_{2} \mathrm{O}_{2}$ treatment induces an increase in MitoSOX staining which is attenuated by both RSV and SRTAW04, and non-differentiated RGC-5 cells showed the same 


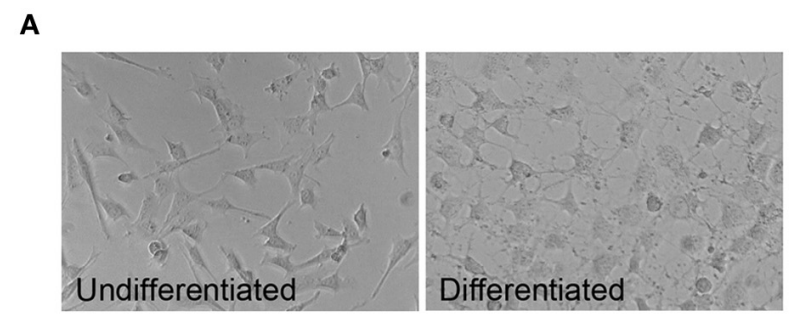

B

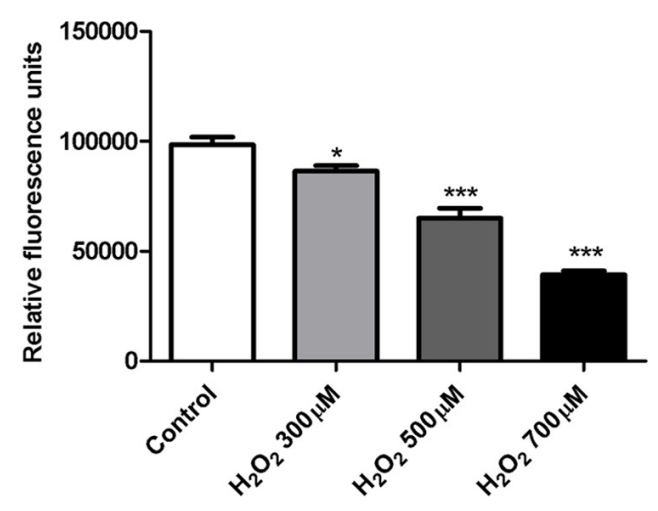

C

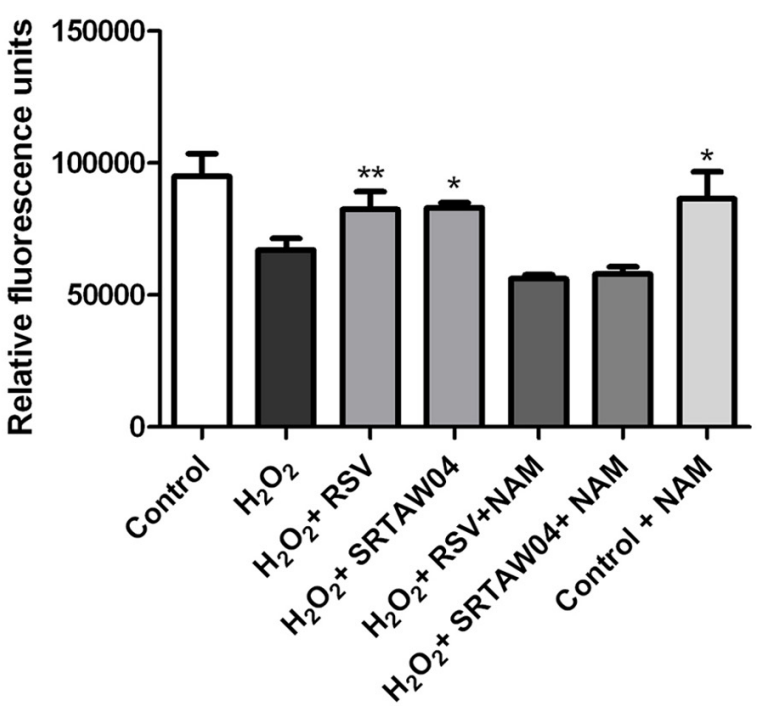

FIGURE 3 | $\mathrm{H}_{2} \mathrm{O}_{2}$-induced loss of neuronal differentiated RGC-5 cells attenuated by SIRT1 activators. (A) RGC-5 cells were plated in serum-containing medium for $16 \mathrm{~h}$ and then differentiated into neurite-sprouting neuronal cells by addition of $1 \mu \mathrm{M}$ staurosporine for $6 \mathrm{~h}$. Phase-contrast photographs demonstrate morphologic changes, including presence of neurites, in differentiated cells. (B) Twenty-four hours treatment of differentiated RGC-5 cells with varying doses of $\mathrm{H}_{2} \mathrm{O}_{2}$ shows a significant dose dependent decrease in cell viability $1^{*} p<0.05$ for $300 \mu \mathrm{M} \mathrm{H}_{2} \mathrm{O}_{2}$ vs. control; *** $p<0.001$ for $500 \mu \mathrm{M} \mathrm{H}_{2} \mathrm{O}_{2}$ vs. control; *** $p<0.001$ for $700 \mu \mathrm{M} \mathrm{H}_{2} \mathrm{O}_{2}$ vs. control) as measured by PrestoBlue Cell Viability Reagent. (C) Pretreatment with $0.25 \mu \mathrm{M}$ RSV or $5 \mu \mathrm{M}$ of SRTAW04 beginning 30 min before $\mathrm{H}_{2} \mathrm{O}_{2}$ treatment, and continuing through $24 \mathrm{~h}$ exposure to $500 \mu \mathrm{M} \mathrm{H}_{2} \mathrm{O}_{2}$, shows a significant attenuation of RGC-5 death as compared to cells exposed to $\mathrm{H}_{2} \mathrm{O}_{2}$ alone $\left({ }^{*} p<0.05 ;{ }^{* *} p<0.01\right.$ ). The ability of RSV and SRTAW04 to attenuate RGC-5 cell death is blocked by addition of SIRT1 inhibitor NAM $(200 \mu \mathrm{M})$. NAM alone does not alter cell viability. effect (Figure 4A). Quantification of the intensity of MitoSOX staining in differentiated RGC-5 cells shows that this effect is significant (Figure 4B). Untreated differentiated cells showed a small increase in MitoSOX Red staining compared to untreated nondifferentiated cells, suggesting some effect from staurosporine treatment itself.

\section{SRTAW04 AND RSV ATTENUATE $\mathrm{H}_{2} \mathrm{O}_{2}$-INDUCED LOSS OF MITOCHONDRIAL MEMBRANE POTENTIAL}

To determine whether $\mathrm{H}_{2} \mathrm{O}_{2}$ treatment results in loss of mitochondrial membrane potential, and how this is affected by SIRT1 activator treatment, JC-1 staining was used. Staurosporinedifferentiated RGC-5 cells were treated for $24 \mathrm{~h}$ with $500 \mu \mathrm{M}$ $\mathrm{H}_{2} \mathrm{O}_{2}$ with or without $0.25 \mu \mathrm{M}$ RSV or $5 \mu \mathrm{M}$ SRTAW04, and live cell fluorescent microscopy pictures were taken after JC-1 staining. Results reveal minimal remaining red fluorescent labeling of viable, high membrane potential mitochondria in $\mathrm{H}_{2} \mathrm{O}_{2}$ treated cells as compared with healthy control cells (Figure 5). Furthermore, the ratio of green to red fluorescent JC-1 staining showed a significant increase in $\mathrm{H}_{2} \mathrm{O}_{2}$-treated cells compared with control cells. The green to red ratio was significantly lower in $\mathrm{H}_{2} \mathrm{O}_{2}$-treated cells that were also treated with RSV or SRTAW04, as compared to $\mathrm{H}_{2} \mathrm{O}_{2}$-treated cells without SIRT1 activators. Results indicate that $\mathrm{H}_{2} \mathrm{O}_{2}$ treatment disrupts the mitochondrial membrane potential, and this is prevented by treatment with RSV and SRTAW04. While JC-1 stain can be used to mark mitochondrial membrane potential, cell membrane potential may also be detected. Therefore, additional mitochondrial membrane potential detection was performed by staining with TMRM. Results further suggest that $\mathrm{H}_{2} \mathrm{O}_{2}$ treatment disrupts the mitochondrial membrane potential, and treatment with RSV and SRTAW04 prevents this (Figure 5).

\section{RSV AND SRTAW04 REQUIRE SIRT1 ACTIVITY TO PREVENT RGC-5 CELL LOSS}

To confirm whether the ability of RSV and SRTAW04 to prevent loss of RGC- 5 cells is dependent on SIRT1 activity, RGC-5 cells were transfected with SIRT1 siRNA or a control siRNA $24 \mathrm{~h}$ prior to addition of $500 \mu \mathrm{M} \mathrm{H}_{2} \mathrm{O}_{2}$ with or without RSV or SRTAW04. RGC-5 cell numbers were quantified $24 \mathrm{~h}$ later. SIRT1 siRNA blocked the ability of RSV and SRTAW04 to prevent RGC-5 cell loss (Figure 6A), whereas control siRNA did not (Figure 6B). SIRT1 protein expression was also measured by Western blotting of extracts from cultures treated with RSV. Results show $\mathrm{H}_{2} \mathrm{O}_{2}$ treatment leads to decreased SIRT1 expression, while RSV treatment significantly limits this decrease (Figure 6C).

\section{EFFECTS OF SIRT1 ACTIVATORS ON EXPRESSION OF MARKERS OF MITOCHONDRIAL AND ANTI-OXIDANT FUNCTION}

RGC-5 cells differentiated with staurosporine were stressed with $500 \mu \mathrm{M} \mathrm{H}_{2} \mathrm{O}_{2}$ for $24 \mathrm{~h}$, with or without addition of $0.25 \mu \mathrm{M}$ RSV, then protein extracts were generated for Western blotting. SDH functions not only in mitochondrial energy generation, but also has a role in oxygen sensing (Baysal, 2006). Protein levels of SDH show a significant decrease during $\mathrm{H}_{2} \mathrm{O}_{2}$ treatment which is attenuated by RSV (Figure 7A). We also 

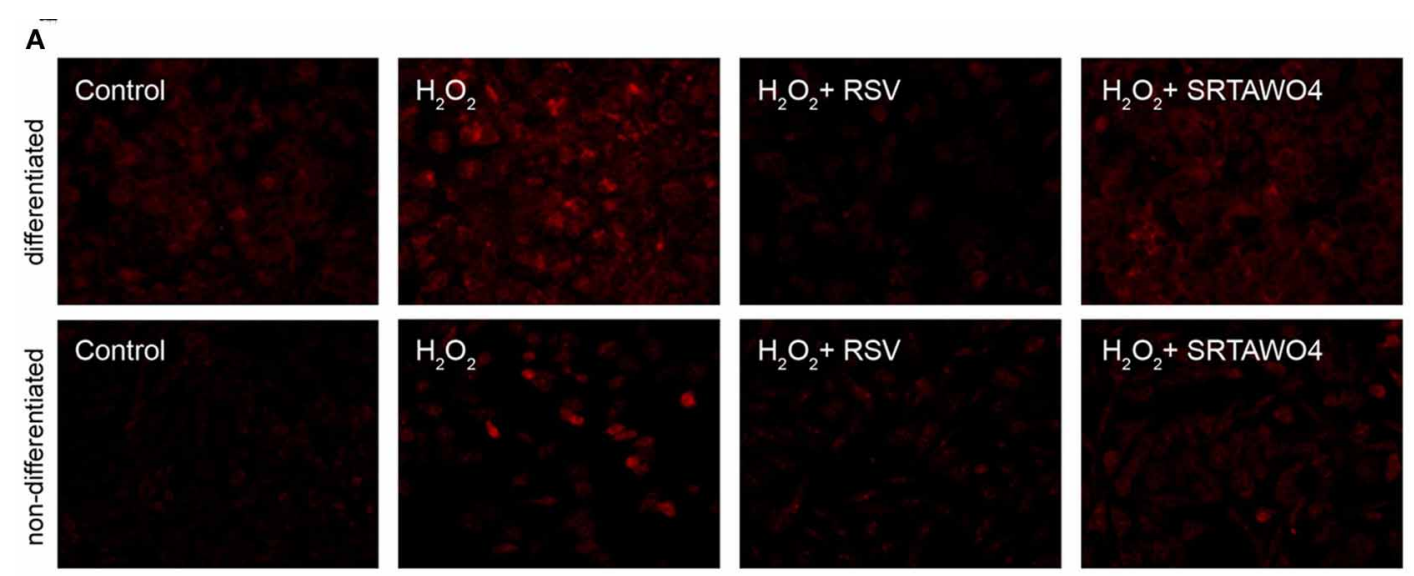

B

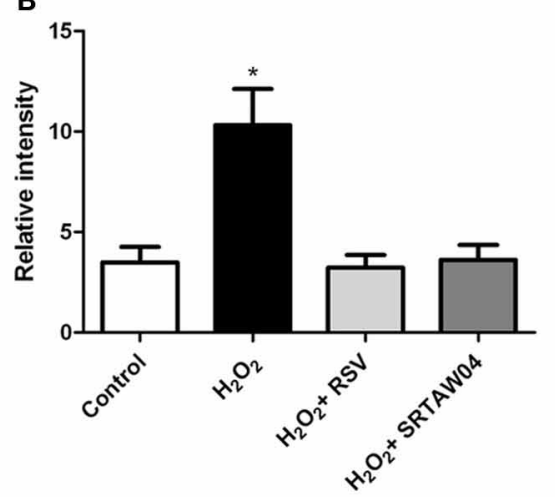

FIGURE 4 | SRTAW04 and RSV attenuate ROS in RGC-5 cells. RGC-5 cells were grown for $24 \mathrm{~h}$ with or without (control) $500 \mu \mathrm{M} \mathrm{H}_{2} \mathrm{O}_{2}$, and treated continuously with $0.25 \mu \mathrm{M}$ RSV or $5 \mu \mathrm{M}$ SRTAW04 where indicated, beginning 30 min before addition of $\mathrm{H}_{2} \mathrm{O}_{2}$. Cells were stained with MitoSOX Red to assess ROS accumulation. (A) Significant attenuation of MitoSOX staining is shown in representative cultures treated with RSV and SRTAW04 compared to untreated $\mathrm{H}_{2} \mathrm{O}_{2}$-containing cultures for both non-differentiated (top) and differentiated (bottom) RGC-5 cells. (B) The average intensity of MitoSOX staining is significantly higher in $\mathrm{H}_{2} \mathrm{O}_{2}$ cultures as compared to control cultures (* $p<0.05)$, and compared to RSV $\left({ }^{*} p<0.05\right)$ and SRTAW04 $(* p<0.05)$ treated cultures of differentiated RGC-5 cells. measured the protein expression levels of SOD2, a mitochondrial protein which binds to superoxide byproducts of oxidative phosphorylation and converts them to hydrogen peroxide and diatomic oxygen (Suski et al., 2012). Results show a significant decrease in levels of SOD2 during $\mathrm{H}_{2} \mathrm{O}_{2}$ treatment, and treatment with RSV significantly limits this decrease (Figure 7B).

The peroxisome proliferator activated receptor (PPAR) coactivator 1- $\alpha$ (PGC-1 $\alpha)$ is a transcriptional co-activator identified as an upstream regulator of mitochondrial number and function (Russell et al., 2004) and is activated by SIRT1-mediated deacetylation (Lagouge et al., 2006). RGC-5 cell protein extracts were immunoprecipitated with PGC- $1 \alpha$ antibody. Western blot of the precipitated protein was probed with either PGC- $1 \alpha$ antibody, or antibody to acetylated lysine, and the ratio of acetylated to deacetylated PGC- $1 \alpha$ was compared. Results show a significant increase in acetylated lysine antibody immunoreactivity following $\mathrm{H}_{2} \mathrm{O}_{2}$ treatment, compared to control cells, as well as compared to RSV and SRTAW04 treated RGC-5 cells (Figure 7C). Overall PGC-1 $\alpha$ expression showed no significant change between culture conditions. When compared, the decreased ratio of acetylated lysine to PGC-1 $\alpha$ immunoreactivity in RSV and SRTAW04 treated cells demonstrates SIRT1 activators prevent an increase in PGC- $1 \alpha$ acetylation.

\section{RESVERATROL PREVENTS LOSS OF PRIMARY RGCs}

While RGC- 5 cells differentiated with staurosporine exhibit some features of neurons, they are not a RGC specific cell line. Because optic neuritis and other optic neuropathies lead specifically to RGC loss, effects of RSV were further examined in primary retinal cell cultures, and RGC survival was assessed. Mixed dissociated retinal cells isolated from neonatal days 3 to 5 mice were incubated overnight, transfected for $24 \mathrm{~h}$ with SIRT1 specific or control siRNA, then treated for $24 \mathrm{~h}$ with $500 \mu \mathrm{M} \mathrm{H}_{2} \mathrm{O}_{2}$ with or without addition of RSV $(3 \mu \mathrm{M})$. RGCs were identified within the mixed retinal cell cultures by immunohistochemical staining with antibodies to Brn3a (Figure 8A), and the number of RGCs was quantified by counting Brn3a positive cells by a blinded investigator. As seen in RGC-5 cells, $\mathrm{H}_{2} \mathrm{O}_{2}$ induced significant loss of primary RGCs, and RGC loss was reduced by treatment with RSV (Figure 8B). To determine whether the mechanism of this effect involves SIRT1 activity, primary RGC cultures were pretreated 

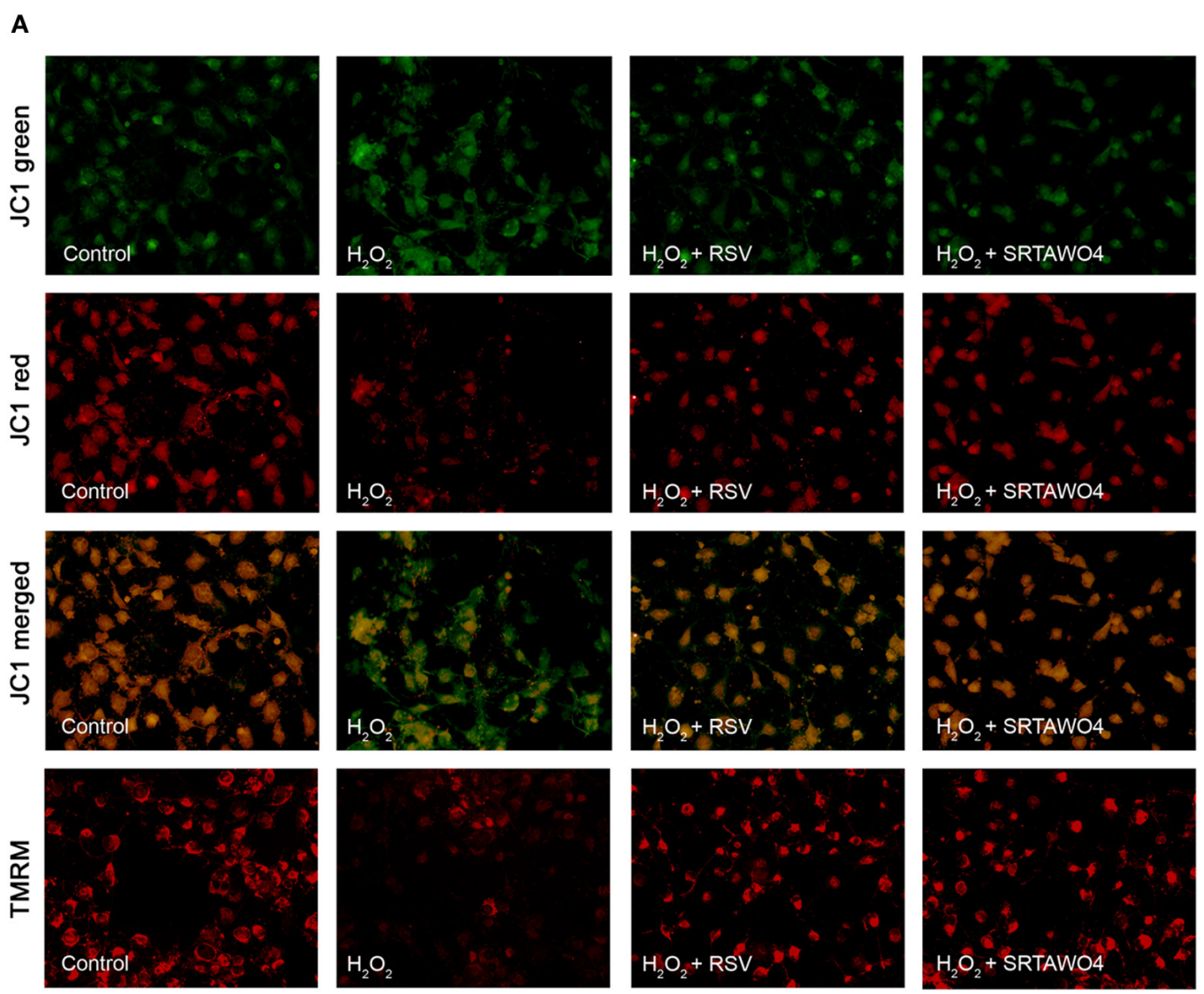

B

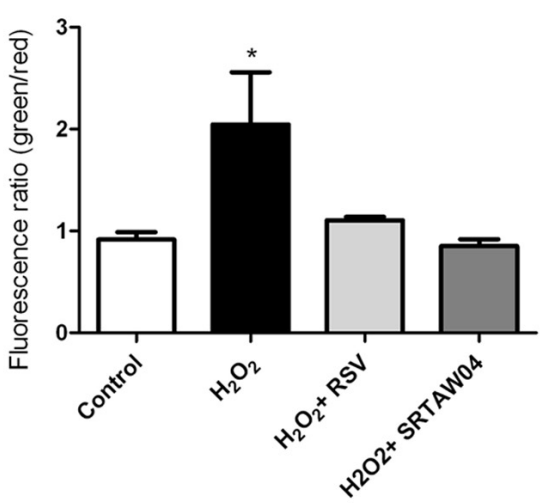

FIGURE 5 | SRTAW04 and RSV attenuate $\mathrm{H}_{2} \mathrm{O}_{2}$ induced loss of mitochondrial potential. RGC-5 cells were plated in serum-containing medium for $16 \mathrm{~h}$ and then differentiated into neuronal cells by addition of $1 \mu \mathrm{M}$ staurosporine for $6 \mathrm{~h}$. Differentiated RGC-5 cells were maintained for $24 \mathrm{~h}$ with or without (control) $500 \mu \mathrm{M} \mathrm{H}_{2} \mathrm{O}_{2}$, and treated with $0.25 \mu \mathrm{M}$ RSV or $5 \mu \mathrm{M}$ SRTAW04 where indicated, beginning 30 min before addition of $\mathrm{H}_{2} \mathrm{O}_{2}$. JC-1 and TMRM stains were used to assess mitochondrial membrane potential. (A) For comparison, a representative field containing similar cell numbers was photographed from each culture (despite overall lower cell numbers in cultures containing $\mathrm{H}_{2} \mathrm{O}_{2}$ without SIRT1 activators). Green JC-1 staining (top row) labeling all mitochondria, including those with low membrane potential, demonstrates similar mitochondrial numbers in each culture. Red JC-1 staining (second row) labeling of normal
C

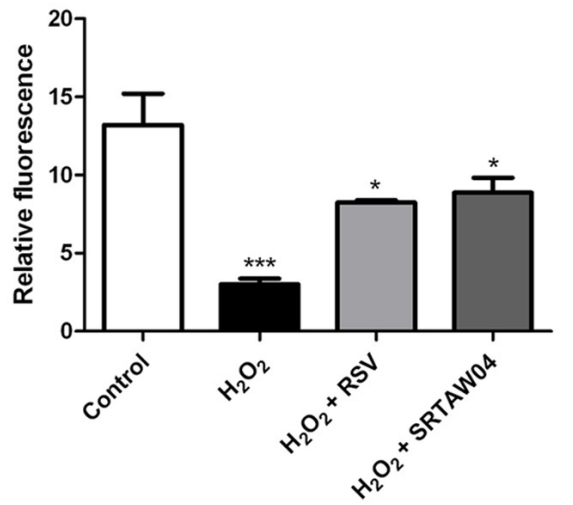

mitochondria shows significant loss of membrane potential in cells exposed to $\mathrm{H}_{2} \mathrm{O}_{2}$, and this is reversed by addition of RSV or SRTAW04. Merged images of green and red JC-1 staining (third row) show a high green to red ratio in cells exposed to $\mathrm{H}_{2} \mathrm{O}_{2}$, with a lower ratio following addition of RSV or SRTAW04. Red TMRM staining (bottom row) of normal mitochondria shows similar loss of membrane potential in cells exposed to $\mathrm{H}_{2} \mathrm{O}_{2}$ that is reversed by addition of RSV or SRTAW04. (B) The average ratio of green to red staining of $\mathrm{JC}-1$ is significantly higher in $\mathrm{H}_{2} \mathrm{O}_{2}$ cultures as compared to control cultures $(* p<0.05)$, and compared to RSV $(* p<0.05)$ and SRTAW04 $(* p<0.05)$ treated cultures. (C) The average intensity of TMRM staining is significantly lower in $\mathrm{H}_{2} \mathrm{O}_{2}$ cultures as compared to control cultures (*** $p<0.001)$, and compared to RSV $(* p<0.05)$ and SRTAW04 $(* p<0.05)$ treated cultures. 


\section{A}

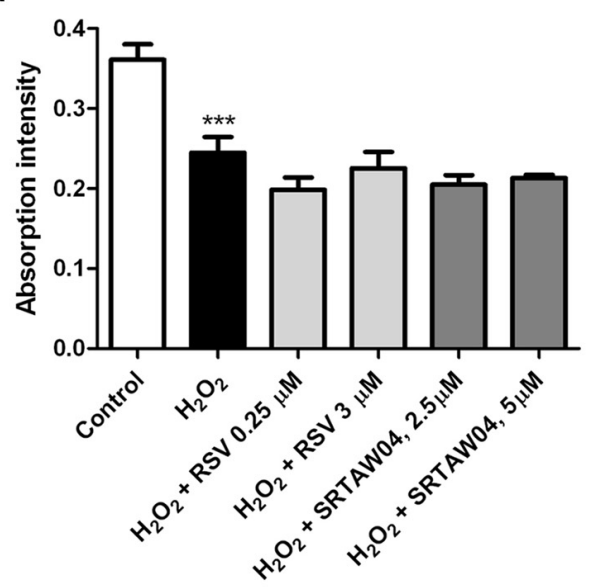

B

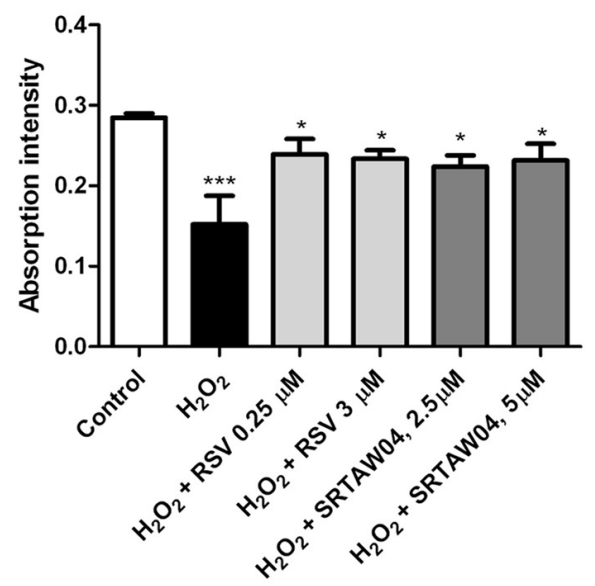

C

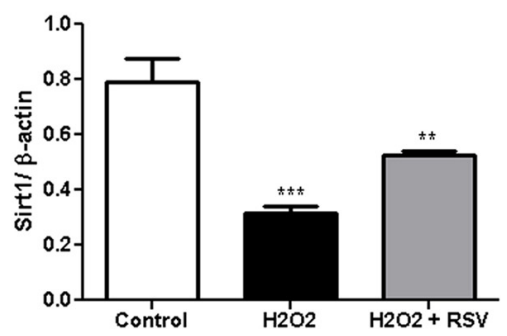

SIRT-1

$\beta$-actin

FIGURE 6 | RSV and SRTAW04 protection of RGC-5 cells is SIRT1-dependent. Staurosporine-differentiated RGC-5 cells were transfected with SIRT1 siRNA (A) or a control siRNA (B) and cultured with or without $500 \mu \mathrm{M} \mathrm{H}_{2} \mathrm{O}_{2}$, and with or without RSV $(0.25$ and $3 \mu \mathrm{M})$ or SRTAW04 (2.5 and $5 \mu \mathrm{M})$ as indicated. SIRT1 siRNA blocked the ability of RSV and SRTAW04 to prevent loss of RGC- 5 cells ( $* * * p<0.001$ vs. controls). This effect is specific to SIRT1, as RSV and SRTAW04 do prevent $\mathrm{H}_{2} \mathrm{O}_{2}$-induced RGC-5 loss in cells transfected with control siRNA $\left({ }^{*} p<0.05\right)$. (C) Expression of SIRT1 was measured by Western blot of protein extracts from RSV-treated RGC- 5 cultures not transfected with siRNA. Twenty-four hours after initiation of treatment, $\mathrm{H}_{2} \mathrm{O}_{2}$ shows a significant decrease of SIRT1 protein expression $(* * * p<0.001)$, whereas treatment with RSV significantly attenuates this decrease $\left.{ }^{* *} p<0.01\right)$.
A

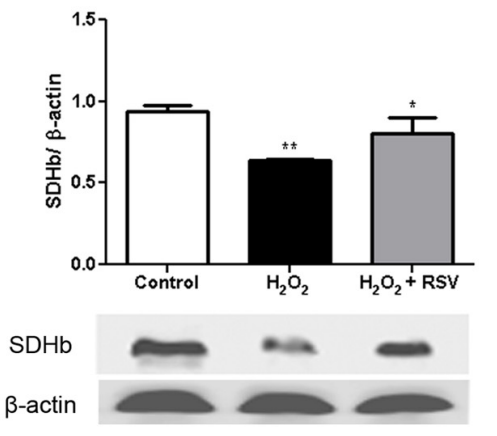

B
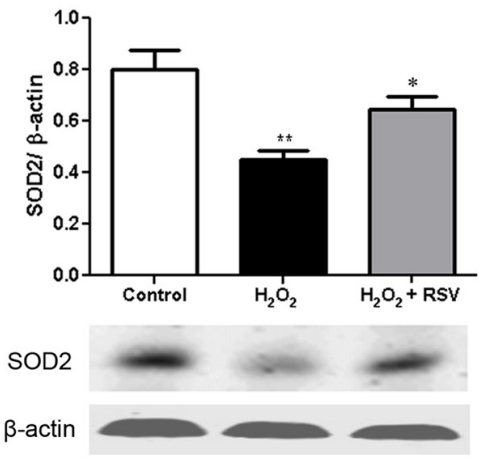

C
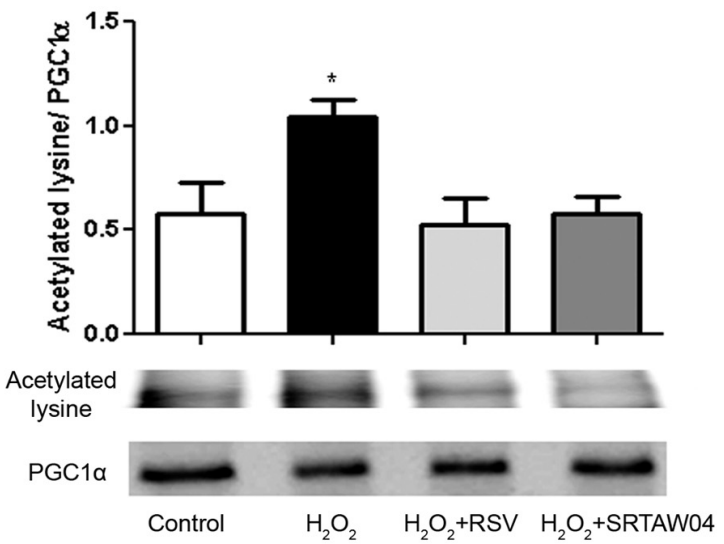

FIGURE 7 | RSV treatment increases markers of mitochondrial function in stressed RGC-5 cells. Staurosporine-differentiated RGC-5 cells were cultured with or without $500 \mu \mathrm{M} \mathrm{H}_{2} \mathrm{O}_{2}$, and with or without $0.25 \mu \mathrm{M}$ RSV for $24 \mathrm{~h}$. (A) Western blot analysis shows a significant decrease in SDH expression (** $p<0.01$ ) during $\mathrm{H}_{2} \mathrm{O}_{2}$ treatment which is attenuated by treatment with $\mathrm{RSV}(* p<0.05)$. (B) Western blot analysis shows similar effects on SOD2 expression. The significant decrease (** $p<0.01)$ during $\mathrm{H}_{2} \mathrm{O}_{2}$ treatment, compared to controls, is not found in cells treated with RSV $(* p<0.05)$. (C) Protein extracts were immunoprecipitated with anti-PGC-1 $\alpha$ antibodies, blotted, and hybridized with anti-PGC-1 $\alpha$ and anti-acetylated lysine antibodies to assess the acetylation state of PGC-1 $\alpha$. $\mathrm{H}_{2} \mathrm{O}_{2}$ treatment significantly increases the proportion of acetylated PGC- $1 \alpha$ $(* p<0.05)$ compared to controls, and RSV and SRTAW04 treatment each prevent this acetylation $(* p<0.05)$. 
A

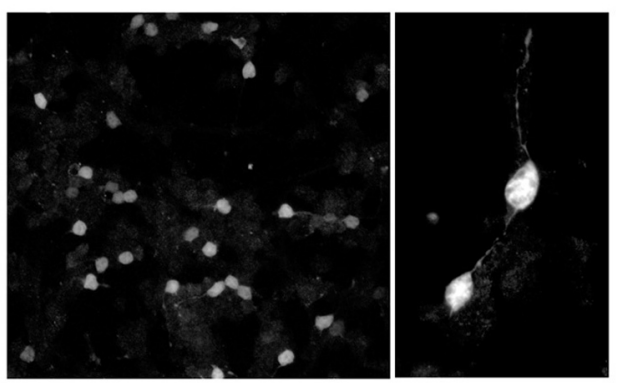

B

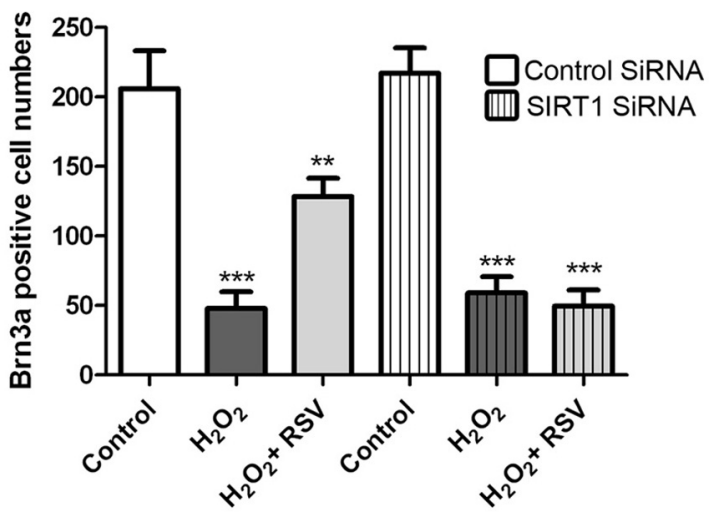

FIGURE 8 | SIRT1 activators prevent loss of primary RGCs. Retinal cells were dissociated from neonatal mice and plated overnight prior to transfection with siRNA for $24 \mathrm{~h}$ and then treated $24 \mathrm{~h}$ with $500 \mu \mathrm{M} \mathrm{H} \mathrm{H}_{2} \mathrm{O}_{2}$ with or without $3 \mu \mathrm{M}$ RSV. Cells were stained with antibodies to Brn3a to detect RGCs within mixed retinal cell cultures, and numbers of Brn3a positive cells were counted. (A) Brn3a staining demonstrates the presence of RGCs with neuronal morphology in these primary cultures. Original magnification $\times 20$ (left) and $\times 63$ (right). (B) $\mathrm{H}_{2} \mathrm{O}_{2}$ induces a significant decrease in the number of RGCs $(* * * p<0.001)$ which is attenuated by treatment with RSV (** $p<0.01$ ) in the presence of control siRNA. SIRT1 siRNA transfection blocks the ability of RSV to attenuate RGC loss, as cell numbers remain significantly reduced compared to controls $(* * * p<0.001)$.

with SIRT1 siRNA. RSV neuroprotection of RGCs was blocked by SIRT1 siRNA but not by control siRNA (Figure 8B).

\section{DISCUSSION}

In the current studies, we demonstrated that two SIRT1 activating compounds, RSV, a naturally occurring plant polyphenol (Siemann and Creasey, 1992; Dong, 2003), and SRTAW04, a compound that activates SIRT1 at an order of magnitude lower concentration, similar to other SIRT1 activators (Milne et al., 2007), both significantly reduce loss of RGC-5 cells in response to several different stressors. SRTAW04 is a member of the same family and exhibits similar chemical properties of SIRT1 activation as the previously described compound 14 in studies by Dai and colleagues (Dai et al., 2010; Dr. Robert Perni, pers. communication). Results in the current study demonstrating that SIRT1 siRNA blocks the protective effects on stressed cells are also consistent with SRTAW04 and RSV functioning through
SIRT1 activity in RGC-5 cells. While RSV is a known activator of SIRT1, treatment also resulted in preserved expression of SIRT1 which may explain or at least contribute to SIRT1-mediated neuroprotection.

A common feature of RGC-5 cell loss was increased oxidative stress, as marked by accumulation of superoxide. SIRT1 activating compounds significantly reduced the level of ROS within cells, suggesting that reduction of oxidative stress is one major mechanism of SIRT1 activator-mediated neuroprotection. Attenuation of RSV and SRTAW04 neuroprotective effects by a known SIRT1 inhibitor, NAM, further suggests that the mechanism of these effects is dependent on the ability of these compounds to activate SIRT1. Interestingly, NAM has been found to be neuroprotective in some neuronal injury models, due to its ability to inhibit PARP1 (Liu et al., 2009). Those studies used much higher concentrations of NAM than in the current the studies, which may explain why NAM alone had no effect on RGC-5 cells.

We previously showed that RSV and other SIRT1 activators reduce RGC loss in EAE models of optic neuritis (Shindler et al., 2007, 2010; Fonseca-Kelly et al., 2012), and therefore provide an important potential therapy to prevent the neuronal damage that leads to permanent neurologic disability in optic neuritis and MS patients. To further elucidate the mechanism by which SIRT1 activators are able to prevent RGC loss, in the present study we investigated effects of two SIRT1 activating compounds on differentiated and non-differentiated neuronal cultures. However, while original reports suggested the RGC-5 cell line is a transformed proliferating cell line that expresses some RGC-specific markers (Krishnamoorthy et al., 2001; Wood et al., 2010), it is important to note that the lineage and characteristics of this cell line has since been found to be different (Van Bergen et al., 2009), with features of photoreceptors, and limits the relevance of current results to optic nerve disease. For most of our experiments we used differentiated RGC-5 cells because sub-lethal treatment with staurosporine induces differentiation of RGC-5 cells to a non-mitotic phenotype with neurite outgrowth and expression of at least one neuronal ion channel (Frassetto et al., 2006), making them a better model for the study of neuronal cell properties than non-differentiated RGC5 cells. Importantly, SIRT1-dependent protective effects of RSV were also found in primary retinal cultures, suggesting that the current findings may be indicative of RGC responses and have the potential to translate to mechanisms active in optic nerve diseases.

Oxidative stress plays an important role in the pathophysiology of optic neuritis. Studies have demonstrated that inflammatory cells act as mediators of optic nerve injury by release of ROS into the extracellular microenvironment (Guy et al., 1994), with accumulation of ROS in RGC axons in the optic nerve (Qi et al., 2007). Consistent with these previous studies, we found an increase in the superoxide ROS in optic nerve sections of EAE mice. Furthermore, we showed that different stressors, serum starvation, doxorubicin, and $\mathrm{H}_{2} \mathrm{O}_{2}$, induce a similar significant increase in ROS levels in RGC-5 cell cultures, making this a useful model for studying mechanisms of neuronal loss and neuroprotection. The specific use of $\mathrm{H}_{2} \mathrm{O}_{2}$ in RGC-5 cell and primary RGC cultures may be especially relevant because prior reports showed 
that $\mathrm{H}_{2} \mathrm{O}_{2}$ plays a major role in the pathogenesis of optic neuritis (Guy et al., 1993), marked by the presence of $\mathrm{H}_{2} \mathrm{O}_{2}$ in optic nerves of animals with acute EAE, and during the primary stage of demyelination, the optic nerve head is a site of $\mathrm{H}_{2} \mathrm{O}_{2}$ localization derived from sensitized inflammatory cells.

Mitochondria are the primary source of cellular ROS. Increased ROS activity is linked to neurodegenerative diseases that have axonal and neuronal loss as a major feature (Kalman and Leist, 2003). In addition, SIRT1 activation has been shown previously to promote mitochondrial biogenesis in some tissues, including muscle (Lagouge et al., 2006). Thus, we hypothesized that the mechanism of SIRT1 activator-mediated reduction of oxidative stress in RGC-5 cells occurs due to promotion of mitochondrial function, as well as due to increased levels of enzymes that reduce oxidative stress. Consistent with this, we found that SIRT1 activators induce a significant increase in SOD2 in RGC-5 cells. SOD2 is a crucial scavenger for superoxide in mitochondria. SOD2 converts superoxide to $\mathrm{H}_{2} \mathrm{O}_{2}$ and mitochondrial glutathione peroxidase $\mathrm{GPx} 1$ catalyzes the reduction of $\mathrm{H}_{2} \mathrm{O}_{2}$ to $\mathrm{H}_{2} \mathrm{O}$ (Li et al., 2000). Increase in SOD2 expression is a downstream target of SIRT1, and consistent with our results, previous studies showed SIRT1-induced superoxide dismutase, which was further enhanced by RSV, increased the resistance of $\mathrm{C} 2 \mathrm{C} 12$ myoblasts to oxidative stress (Tanno et al., 2010).

We also found SIRT1 activators increase SDH expression in stressed RGC-5 cells. SDH not only plays a central role in the Krebs cycle and the respiratory chain, but it also differs from other mitochondrial dehydrogenases due to its unique redox properties (Balietti et al., 2009). In partnership with ubiquinone, SDH represents a crucial antioxidant enzyme in mitochondria controlling superoxide scavenging activity of the respiratory chain. When succinate-ubiquinone activity is inhibited, electrons that would normally transfer through the SDHB subunit to the ubiquinone pool are instead transferred to $\mathrm{O}_{2}$ to create ROS such as superoxide (Rustin et al., 2002). It has been suggested that the SDHB mutation results in a complete loss of electron transport chain complex II activity in mitochondria (GimenezRoqueplo et al., 2002). As a possible protective mechanism, we investigated the preservation of mitochondrial membrane

\section{REFERENCES}

Andreyev, A. Y., Kushnareva, Y. E., and Starkov, A. A. (2005). Mitochondrial metabolism of reactive oxygen species. Biochemistry 70 , 200-214.

Arnold, A. C. (2005). Evolving management of optic neuritis and multiple sclerosis. Am. J. Ophthalmol. 139, 1101-1108.

Balietti, M., Fattoretti, P., Giorgetti, B., Casoli, T., Di Stefano, G., Solazzi, M., et al. (2009). A ketogenic diet increases succinic dehydrogenase activity in aging cardiomyocytes. Ann. N.Y. Acad. Sci. 1171, 377-384.

Barger, J. L., Kayo, T., Vann, J. M., Arias, E. B., Weindruch, R., and potential using JC-1 and TMRM staining. Oxidative stress alters mitochondrial permeability by opening transition pores, and collapses the mitochondrial membrane potential (Niimi et al., 2012), a major driving force for oxidative phosphorylation. Under chronic oxidative stress, mitochondria can be subject to irreversible increase in permeability of the inner mitochondrial membrane resulting in collapse of membrane potential, and the current data showing preserved JC-1 and TMRM staining suggest that SIRT1 activators prevent this collapse in stressed RGC-5 cells.

Finally, SIRT1 activation induces mitochondrial biogenesis in various tissues (Lagouge et al., 2006; Rasbach and Schnellmann, 2008; Gurd et al., 2009). Mitochondrial biogenesis is a highly regulated process operating through PGC- $1 \alpha$-dependent nuclear respiratory factors. PGC- $1 \alpha$ is heavily acetylated by acetyltransferase GCN5 whereas it is deacetylated by SIRT1 (Gerhart-Hines et al., 2007). SIRT1-mediated deacetylation and activation of PGC-1 $\alpha$ therefore serves as an important response of the cell to increase mitochondrial metabolism.

Together, results demonstrate that SIRT1 activation prevents accumulation of ROS and cell loss, suggesting that this is one mechanism that SIRT1 activators can use to prevent neuronal loss. Results indicate that the mechanism of RSV effects involve SIRT1 activity, and associated deacetylation of PGC- $1 \alpha$ is likely to be involved in the positive regulation of oxidative metabolism, and co-regulates the induction of other proteins like SDH and SOD2 that participate in the cellular response to oxidative stress. The common mechanism of oxidative stress found in many neurodegenerative processes suggests that SIRT1 activators may exert similar anti-oxidative effects as potential neuroprotectants in a variety of neurodegenerative diseases.

\section{ACKNOWLEDGMENTS}

This work was supported by National Institutes of Health grants EY015098 and EY019014, grant RG 4214-A-1 from the National Multiple Sclerosis Society, Research to Prevent Blindness, and the F. M. Kirby Foundation. SIRT1 activating compound SRTAW04 was provided at no charge by Sirtris, a GSK Company.
Prolla, T. A. (2008). A low dose of dietary resveratrol partially mimics caloric restriction and retards aging parameters in mice. PLOS ONE 3:e2264. doi: 10.1371/journal.pone. 0002264

Baur, J. A. (2010). Biochemical effects of SIRT1 activators. Biochim. Biophys. Acta 1804, 1626-1634.

Baur, J. A., Pearson, K. J., Price, N. L., Jamieson, H. A., Lerin, C., Kalra, A., et al. (2006). Resveratrol improves health and survival of mice on a high-calorie diet. Nature 444, 337-342.

Baysal, B. E. (2006). A phenotypic perspective on Mammalian oxygen sensor candidates. Ann. N.Y. Acad. Sci. 1073, 221-233.
Burkitt, M. J., and Duncan, J. (2000). Effects of trans-resveratrol on copper-dependent hydroxyl-radical formation and DNA damage: evidence for hydroxyl radical scavenging and a novel, glutathione-sparing mechanism of action. Arch. Biochem. Biophys. 381, 253-263.

Chu, L. M., Lassaletta, A. D., Robich, M. P., and Sellke, F. W. (2011). Resveratrol in the prevention and treatment of coronary artery disease. Curr. Atheroscler. Rep. 13, 439-446.

Cossarizza, A., Baccarani-Contri, M., Kalashnikova, G., and Franceschi, C. (1993). A new method for the cytofluorimetric analysis of mitochondrial membrane potential using the J-aggregate forming lipophilic cation $5,5^{\prime}, 6,6^{\prime}$ tetrachloro- $1,1^{\prime}, 3,3^{\prime}$ - tetraethylbenzimidazolcarbocyanine iodide (JC-1). Biochem. Biophys. Res. Commun. 197, 40-45.

Cowden, W. B., Cullen, F. A., Staykova, M. A., and Willenborg, D. O (1998). Nitric oxide is a potential down-regulating molecule in autoimmune disease: inhibition of nitric oxide production renders PVG rats highly susceptible to EAE. J. Neuroimmunol. 88, $1-8$.

Dai, H., Kustigian, L., Carney, D., Case, A., Considine, T., Hubbard, B. P., et al. (2010). SIRT1 activation by 
small molecules: kinetic and biophysical evidence for direct interaction of enzyme and activator. J. Biol. Chem. 285, 32695-32703.

De la Lastra, C. A., and Villegas, I. (2005). Resveratrol as an antiinflammatory and anti-aging agent: mechanisms and clinical implications. Mol. Nutr. Food Res. 49, 405-430.

Dong, Z. (2003). Molecular mechanism of the chemopreventive effect of resveratrol. Mutat. Res. 523-524, 145-150.

Fisher, J. B., Jacobs, D. A., Markowitz, C. E., Galetta, S. L., Volpe, N. J., Nano-Schiavi, M. L., et al. (2006). Relation of visual function to retinal nerve fiber layer thickness in multiple sclerosis. Ophthalmology 113, 324-332.

Fonseca-Kelly, Z., Nassrallah, M., Uribe, J., Khan, R. S., Dine, K., Dutt, M., et al. (2012). Resveratrol neuroprotection in a chronic mouse model of multiple sclerosis. Front. Neurol. 3:84. doi: 10.3389/fneur.2012.00084

Frassetto, L. J., Schlieve, C. R., Lieven, C. J., Utter, A. A., Jones, M. V., Agarwal, N., et al. (2006). Kinasedependent differentiation of a retinal ganglion cell precursor. Invest. Ophthalmol. Vis. Sci. 47, 427-438.

Gerhart-Hines, Z., Rodgers, J. T., Bare, O., Lerin, C., Kim, S. H., Mostoslavsky, R., et al. (2007). Metabolic control of muscle mitochondrial function and fatty acid oxidation through SIRT1/PGC-1alpha. EMBO J. 26, 1913-1923.

Gimenez-Roqueplo, A. P., Favier, J., Rustin, P., Rieubland, C., Kerlan, V., Plouin, P. F., et al. (2002). Functional consequences of a SDHB gene mutation in an apparently sporadic pheochromocytoma. J. Clin. Endocrinol. Metab. 87, 4771-4774.

Guan, Y., Shindler, K. S., Tabuena, P., and Rostami, A. (2006). Retinal ganglion cell damage induced by spontaneous autoimmune optic neuritis in MOG-specific TCR transgenic mice. J. Neuroimmunol. $178,40-48$.

Gurd, B. J., Yoshida, Y., Lally, J., Holloway, G. P., and Bonen, A. (2009). The deacetylase enzyme SIRT1 is not associated with oxidative capacity in rat heart and skeletal muscle and its overexpression reduces mitochondrial biogenesis. J. Physiol. 587, 1817-1828.

Guy, J., McGorray, S., Fitzsimmons, J., Beck, B., and Rao, N. A. (1994). Disruption of the blood-brain barrier in experimental optic neuritis: immunocytochemical co-localization of $\mathrm{H}_{2} \mathrm{O}_{2}$ and extravasated serum albumin. Invest. Ophthalmol. Vis. Sci. 35, 1114-1123.

Guy, J., Ellis, E. A., Mames, R., and Rao, N. A. (1993). Role of hydrogen peroxide in experimental optic neuritis. A serial quantitative ultrastructural study. Ophthalmic. Res. 25, 253-264.

Heng, J. E., Vorwerk, C. K., Lessell, E., Zurakowski, D., Levin, L. A., and Dreyer, E. B. (1999). Ethamubutol is toxic to retinal ganglion cells via an excitotoxic pathway. Invest. Ophthalmol. Vis. Sci. 40, 190-196.

Imai, S., Armstrong, C. M., Kaeberlein, M., and Guarente, L. (2000). Transcriptional silencing and longevity protein Sir2 is an NADdependent histone deacetylase. Nature 403, 795-800.

Kalman, B., and Leist, T. P. (2003). A mitochondrial component of neurodegeneration in multiple sclerosis. Neuromol. Med. 3, 147-158.

Krishnamoorthy, R. R., Agarwal, P., Prasanna, G., Vopat, K., Lambert, W., Sheedlo, H. J., et al. (2001). Characterization of a transformed rat retinal ganglion cell line. Brain Res. Mol. Brain Res. 86, 1-12.

Lagouge, M., Argmann, C., GerhartHines, Z., Meziane, H., Lerin, C., Daussin, F., et al. (2006). Resveratrol improves mitochondrial function and protects against metabolic disease by activating SIRT1 and PGC1alpha. Cell 127, 1109-1122.

Li, S., Yan, T., Yang, J. Q., Oberley, T. D., and Oberley, L. W. (2000). The role of cellular glutathione peroxidase redox regulation in the suppression of tumor cell growth by manganese superoxide dismutase. Cancer Res. 60, 3927-3939.

Lieven, C. J., Hoegger, M. J., Schlieve, C. R., and Levin, L. A. (2006). Retinal ganglion cell axotomy induces an increase in intracellular superoxide anion. Invest. Ophthalmol. Vis. Sci. 47, 1477-1485.

Liu, D., Gharavi, R., Pitta, M., Gleichmann, M., and Mattson, M. P. (2009). Nicotinamide prevents NAD+ depletion and protects neurons against excitotoxicity and cerebral ischemia: NAD+ consumption by SIRT1 may endanger energetically compromised neurons. Neuromolecular Med. 11, 28-42.

Milne, J. C., Lambert, P. D., Schenk, S., Carney, D. P., Smith, J. J., Gagne, D. J., et al. (2007). Small molecule activators of SIRT1 as therapeutics for the treatment of type 2 diabetes. Nature 450, 712-716.

Mohamed, A., Shoker, A., Bendjelloul, F., Mare, A., Alzrigh, M., Benghuzzi, H., et al. (2003).
Improvement of experimental allergic encephalomyelitis (EAE) by thymoquinone; an oxidative stress inhibitor. Biomed. Sci. Instrum. 39, 440-445.

Murias, M., Jager, W., Handler, N., Erker, T., Horvath, Z., Szekeres, T., et al. (2005). Antioxidant, prooxidant and cytotoxic activity of hydroxylated resveratrol analogues: structure-activity relationship. Biochem. Pharmacol. 69, 903-912.

Niimi, K., Yasui, T., Hirose, M. Hamamoto, S., Itoh, Y., Okada, A., et al. (2012). Mitochondrial permeability transition pore opening induces the initial process of renal calcium crystallization. Free Radic. Biol. Med. 52, 1207-1217.

Pallàs, M., Casadesús, G., Smith, M. A., Coto-Montes, A., Pelegri, C., Vilaplana, J., et al. (2009). Resveratrol and neurodegenerative diseases: activation of SIRT1 as the potential pathway towards neuroprotection. Curr. Neurovasc. Res. 6, 70-81.

Qi, X., Lewin, A. S., Hauswirth, W. W., and Guy, J. (2003). Optic neuropathy induced by reductions in mitochondrial superoxide dismutase. Invest. Ophthalmol. Vis. Sci. 44 1088-1096.

Qi, X., Lewin, A. S., Sun, L., Hauswirth, W. W., and Guy, J. (2007). Suppression of mitochondrial oxidative stress provides long-term neuroprotection in experimental optic neuritis. Invest. Ophthalmol. Vis. Sci. 48, 2681-2691.

Quinn, T., Dutt, M., and Shindler, K. S. (2011). Optic neuritis and retinal ganglion cell loss in a chronic murine model of multiple sclerosis. Front. Neurol. 2:50. doi: 10.3389/fneur.2011.00050

Rasbach, K. A., and Schnellmann, R. G. (2008). Isoflavones promote mitochondrial biogenesis. J. Pharmacol. Exp. Ther. 325, 536-543.

Russell, L. K., Mansfield, C. M., Lehman, J. J., Kovacs, A., Courtois, M., and Saffitz, J. E. (2004). Cardiac-specific induction of the transcriptional coactivator peroxisome proliferator-activated receptor gamma coactivator-lalpha promotes mitochondrial biogenesis and reversible cardiomyopathy in a developmental stagedependent manner. Circ. Res. 94, 525-533.

Rustin, P., Munnich, A., and Rötig, A. (2002). Succinate dehydrogenase and human diseases: new insights into a well-known enzyme. Eur. J. Hum. Genet. 10, 289-291.
Shindler, K. S., Ventura, E., Dutt, M., Elliott, P., Fitzgerald, D. C., and Rostami, A. (2010). Oral resveratrol reduces neuronal damage in a model of multiple sclerosis. J. Neuroophthalmol. 30, 328-339.

Shindler, K. S., Ventura, E., Dutt, M., and Rostami, A. M. (2008). Inflammatory demyelination induces axonal injury and retinal ganglion cell apoptosis in experimental optic neuritis. Exp. Eye Res. 87, 208-213.

Shindler, K. S., Guan, Y., Ventura, E., Bennett, J., and Rostami, A. (2006). Retinal ganglion cell loss induced by acute optic neuritis in a relapsing model of multiple sclerosis. Mult. Scler. 12, 526-532.

Shindler, K. S., Ventura, E., Rex, T. S., Elliott, P., and Rostami, A. (2007). SIRT1 activation confers neuroprotection in experimental optic neuritis. Invest. Ophthalmol. Vis. Sci. 48, 3602-3609.

Siemann, E. H., and Creasey, L. L. (1992). Concentration of the phytoalexin resveratrol in wine. Am. J. Enol. Vitic. 43, 49-52.

Sun, B. S., and Spranger, M. I. (2005). Review: quantitative extraction and analysis of grape and wine proanthocyanidins and stilbenes. Ciencia Tec. Vitiv. 20, 59-91.

Suski, J. M., Lebiedzinska, M., Bonora, M., Pinton, P., Duszynski, J., and Wieckowski, M. R. (2012). Relation between mitochondrial membrane potential and ROS formation. Methods Mol. Biol. 810, 183-205.

Tanno, M., Kuno, A., Yano, T., Miura, T., Hisahara, S., Ishikawa, S., et al. (2010). Induction of manganese superoxide dismutase by nuclear translocation and activation of SIRT1 promotes cell survival in chronic heart failure. J. Biol. Chem. 285, 8375-8382.

Trip, S. A., Schlottmann, P. G., Jones, S. J., Altmann, D. R., GarwayHeath, D. F., Thompson, A. J., et al. (2005). Retinal nerve fiber layer axonal loss and visual dysfunction in optic neuritis. Ann. Neurol. 58, 383-391.

Van Bergen, N. J., Wood, J. P., Chidlow, G., Trounce, I. A., Casson, R. J., Ju, W. K., et al. (2009). Recharacterization of the RGC5 retinal ganglion cell line. Invest. Ophthalmol. Vis. Sci. 50, 4267-4272.

Wang, G. L., Fu, J. C., Xu, W. C. Feng, Y. Q., Fang, S. R., and Zhou, X. H. (2009). Resveratrol inhibits the expression of SREB1 in cell model of steatosis via SIRT1FOXO1 signaling pathway. Biochem. 
Biophys. Res. Commun. 380, 644-649.

Wood, J. P., Chidlow, G., Tran, T., Crowston, J. G., and Casson, R. J. (2010). A comparison of differentiation protocols for RGC-5 cells. Invest. Ophthalmol. Vis. Sci. 51, 3774-3783.

Yang, T., and Sauve, A. A. (2006). NAD metabolism and sirtuins: metabolic regulation of protein deacetylation in stress and toxicity. AAPS J. 8, E632-E643.

Conflict of Interest Statement: The authors declare that the research was conducted in the absence of any commercial or financial relationships that could be construed as a potential conflict of interest.
Received: 23 August 2012; accepted: 11 December 2012; published online: 31 December 2012.

Citation: Khan RS, Fonseca-Kelly Z, Callinan C, Zuo L, Sachdeva MM and Shindler KS (2012) SIRT1 activating compounds reduce oxidative stress and prevent cell death in neuronal cells. Front. Cell. Neurosci. 6:63. doi: 10.3389/ fncel.2012.00063
Copyright (C) 2012 Khan, Fonseca-Kelly, Callinan, Zuo, Sachdeva and Shindler. This is an open-access article distributed under the terms of the Creative Commons Attribution License, which permits use, distribution and reproduction in other forums, provided the original authors and source are credited and subject to any copyright notices concerning any third-party graphics etc. 